\title{
New and little known crane-fly species of the genera Helius, Elephantomyia and Toxorhina (Diptera, Limoniidae) from Dominican and Mexican amber
}

\author{
Katarzyna Kopeć, Iwona Kania, and Wiesław Krzemiński
}

\begin{abstract}
The descriptions of two new species of limoniid dipterans: Helius (Helius) neali $\mathrm{n}$. sp., Helius (Helius) oosterbroeki n. sp., from Dominican amber and one new species Toxorhina (Ceratocheilus) mexicana $\mathrm{n}$. sp. from Mexican amber are given and documented by photographs and drawings. New information about a new specimen of the known species Elephantomyia grata Podenas and Poinar, 2012 is also provided.
\end{abstract}

Katarzyna Kopeć. Institute of Systematics and Evolution of Animals, Polish Academy of Sciences, 31-016 Kraków, Poland. k_slazyk@poczta.onet.pl Iwona Kania. Department of Environmental Biology, University of Rzeszów, Zelwerowicza 4, 35-601 Rzeszów, Poland. ikania@univ.rzeszow.pl - corresponding author Wiesław Krzemiński. Institute of Biology, Pedagogical University of Kraków, Podbrzezie 3, 31-054 Kraków, Poland. krzeminski@muzeum.pan.krakow.pl

Keywords: fossil insects; inclusions; taxonomy; new species; evolution

Submission: 25 August 2015 Acceptance: 29 June 2016

\section{INTRODUCTION}

The Dominican and Mexican ambers are well known among the fossil resins of Central America. In the Dominican Republic, amber occurs in commercially exploitable quantities in two zones, in the "northern area", north of Santiago de los Caballeros and the "eastern area" northeast of Santo Domingo (Iturralde-Vinent and MacPhee, 1996). The age of the Dominican amber is debatable (Lambert et al., 1985; Grimaldi, 1995; Kimura et al., 2006; Peney, 2010). Amber from the northern area is estimated to be as old as early Eocene or as young as early Miocene, while the age of deposits of amber from eastern area ranges even from Cretaceous to extant times. Generally, all the main amberiferous deposits in the Dominican Republic were probably formed during the early Miocene through middle Miocene, about 15 to $20 \mathrm{Ma}$, according to available biostratigraphic and paleogeographic data (Iturralde-Vinent and MacPhee, 1996; Penney, 2010).

The Mexican amber, besides Baltic and Dominican amber, is one of the most important global resource (Solórzano-Kraemer, 2007). The

http://zoobank.org/17FC7DAA-0270-4B21-BD34-F83D1705293B

Kopeć, Katarzyna, Kania, Iwona, and Krzemiński, Wiesław. 2016. New and little known crane-fly species of the genera Helius, Elephantomyia and Toxorhina (Diptera, Limoniidae) from Dominican and Mexican amber. Palaeontologia Electronica 19.2.25A: 1-14 palaeo-electronica.org/content/2016/1535-a-new-limoniidae-from-miocene 
TABLE 1. A list of fossil species of Limoniidae known from Dominican and Mexican amber.

\begin{tabular}{|c|c|c|}
\hline Genus & Species & Locality \\
\hline \multicolumn{3}{|c|}{ Chioneinae } \\
\hline \multirow[t]{3}{*}{ Erioptera } & Erioptera (Mesocyphona) beata Podenas and Poinar, 2012 & Mexico \\
\hline & Erioptera (Mesocyphona) divera Podenas and Poinar, 2012 & Mexico \\
\hline & Erioptera (Mesocyphona) sherry Podenas and Poinar, 2012 & Mexico \\
\hline \multirow[t]{2}{*}{ Gnophomyia } & Gnophomyia ieva Podenas and Poinar, 1999 & Dominican Republic \\
\hline & Gnophomyia martini Podenas and Poinar, 1999 & Dominican Republic \\
\hline Molophilus & Molophilus (Molophilus) theischingeri Krzemiński, 1992 & Dominican Republic \\
\hline \multirow[t]{2}{*}{ Styringomyia } & Styringomyia dominicana Podenas and Poinar, 1999 & Dominican Republic \\
\hline & Styringomyia optiova Podenas and Poinar, 2001 & Dominican Republic \\
\hline \multicolumn{3}{|c|}{ Limnophilinae } \\
\hline Epiphragma & Epiphragma aurora Podenas and Poinar 2001 & Dominican Republic \\
\hline \multirow[t]{2}{*}{ Polyneura } & Polyneura specula Podenas and Poinar, 1999 & Dominican Republic \\
\hline & Polyneura virgo Podenas and Poinar, 1999 & Dominican Republic \\
\hline & Limoniinae & \\
\hline \multirow[t]{6}{*}{ Dicranomyia } & Dicranomyia (Caenolimonia) alexbrowni Podenas and Poinar, 2012 & Mexico \\
\hline & Dicranomyia (Dicranomyia) chiapa Podenas and Poinar, 2012 & Mexico \\
\hline & Dicranomyia (Dicranomyia) fera Podenas and Poinar, 1999 & Dominican Republic \\
\hline & Dicranomyia (Dicranomyia) lema Podenas and Poinar, 1999 & Dominican Republic \\
\hline & Dicranomyia (Dicranomyia) mexa Podenas and Poinar, 2012 & Mexico \\
\hline & Dicranomyia (Dicranomyia) vela Podenas and Poinar, 2012 & Mexico \\
\hline Elephantomyia & Elephantomyia grata Podenas and Poinar, 2001 & Mexico \\
\hline Geranomyia & Geranomyia euchara Podenas and Poinar, 2001 & Dominican Republic \\
\hline Helius & Helius collemus Podenas and Poinar, 2012 & Mexico \\
\hline Rhipidia & Rhipidia mira Podenas and Poinar 1999 & Dominican Republic \\
\hline \multirow[t]{3}{*}{ Trentepohlia } & Trentepohlia (Parangoma) agri Podenas and Poinar, 1999 & Dominican Republic \\
\hline & Trentepohlia (Parangoma) immemorata Podenas and Poinar, 2001 & Mexico \\
\hline & Trentepohlia (Parangoma) mexicana Podenas and Poinar, 2001 & Mexico \\
\hline
\end{tabular}

age of Mexican amber is estimated to be middle Miocene $(20 \mathrm{Ma})$. Both the Dominican and the Mexican amber can be correlated not only in respect to similarity of age but also on account of the same amber-producing tree, the representative of extant genus Hymenaea (Poinar, 1992; Poinar and Brown, 2002) and geological conditions (Solórzano-Kraemer, 2007).

Although knowledge about the representatives of Limoniidae Speiser, 1909 (Diptera) from this American resins is rather poor, 24 species of Limoniidae are known from Dominican and Mexican amber with three of them belonging to Limnophilinae Bigot, 1854 like Epiphragma aurora Podenas and Poinar, 2001; Polymera specula Podenas and Poinar, 1999 or Polymera virgo Podenas and Poinar, 1999; eight to subfamily Chi- oneinae Rondani, 1841 especially to the genus Gnophomyia Osten-Sacken, 1860 or Erioptera Meigen, 1803; and 13 species belong to subfamily Limoniinae Speiser, 1909, mainly to the genus Dicranomyia Stephens, 1829 or Trentepohlia Bigot, 1854 (Table 1). The information about Limoniidae from Miocene Dominican and Miocene Mexican ambers can be found in papers of Krzemiński (1992), Evenhuis (1994), Podenas and Poinar (1999, 2001, 2012).

This paper presents the description of three new species from the Dominican and Mexican ambers and information about new materials of known species of the genus Elephantomyia Osten Sacken, 1860 from this kind of resins. It also documents the first representative of Toxorhina Loew, 1851 in Mexican amber. 


\section{MATERIAL AND METHODS}

The present study was based on material from the collection of the Smithsonian Institution Entomology Department (NMNH), located in Washington; Brodzinsky/Lopez-Penha Collection (3 specimens) and Natural History Museum (NHM), London, UK (1 specimen). The specimens were studied using a Nikon SMZ 1500 stereomicroscope. The photographs for analysis were taken with a Nikon DS-Fi1 camera attached to a microscope. The drawings were made on the basis of the specimen and photographs. The measurements of the specimen were taken with NIS-Elements D 3.0 software, Nikon Corporation, Tokyo. The nomenclature of wing venation is given after Krzemiński et al. (2010), while the terminology of the male genitalia follows that of Podenas (2003). The drawings were made by Iwona Kania.

\section{SYSTEMATIC PALEONTOLOGY}

Order Diptera Linnaeus, 1758

Family Limoniidae Speiser, 1909

Subfamily Limoniinae Speiser, 1909

Genus ELEPHANTOMYIA Osten Sacken, 1860

Type species. Elephantomyia canadensis (Westwood, 1835).

The genus is represented by more than 130 extant species, which occur mainly in tropical and subtropical regions like: Neotropic, Afrotropic (Oosterbroek, 2015). Over 20 species are represented in oriental region, over 10 species in Palearctic, Australian and Oceanian, while only three species were reported from Nearctic region.

Until recently, only six fossil species have been described, mainly from Eocene Baltic amber (Loew, 1851; Alexander, 1931; Kania, 2015) and one species from Oligocene Dominican amber (Podenas and Poinar, 2001).

\section{Elephantomyia (Elephantomyia) grata Podenas and Poinar, 2001}

Figures 1 and 2

Type material. No. 5546 (sex unknown) Smithsonian Institution Entomology Department; Brodzinsky/Lopez-Penha Collection.

Comparisons. The species was described based on a single specimen. The second specimen, which was found by us, is partially preserved, without the end of abdomen. But the size of the body, wing venation and morphology of antennae correspond to the description of holotype. The small differences are visible: cross-vein $\mathrm{m}$-cu is situated nearer the middle of $d$-cell basal part than in holo- type; the first and the second flagellomeres in examined specimen are joined into fused segment. Additional description. The body (Figure 2.1) is about $3.00 \mathrm{~mm}$ long with rostrum very elongated, longer than half the body length, $3.01 \mathrm{~mm}$ long and antennae $0.88 \mathrm{~mm}$ (Figures 1.1, 1.4, 2.2). Wing (Figures 1.3, 2.1) is $3.50 \mathrm{~mm}$ long, $0.94 \mathrm{~mm}$ wide.

Genus HELIUS Lepeletiere and Serville, 1828

Type species. Helius longirostris (Meigen, 1818).

The genus is represented by more than 240 extant species, occurring mainly in the Oriental region (Oosterbroek, 2015). Almost 50 species are represented in Neotropic and Australian and Oceanian, over 20 species in Palearctic and Afrotropic, but only four species are reported from the Nearctic region.

Until recently, 20 fossil species had been described, mainly from Eocene Baltic amber (Loew, 1850, 1851; Meunier, 1906; Alexander, 1931; Krzemiński 1985, 1993; Podenas, 2002; Kania, 2014), but also from Early Cretaceous of Botswana (Rayner and Waters, 1990), Burma (Ribeiro, 2003), Lebanon (Kania et al., 2013; Krzemiński et al., 2014) and Eocene/Oligocene (Krzemiński, 1991), Oligocene of Germany (Statz, 1934, 1944), Oligocene Dominican amber (Podenas and Poinar, 2001), Miocene of Russia (Krzemiński, 2002), Miocene of Mexico (Podenas and Poinar, 2012).

\section{Helius (Helius) neali n. sp.}

Figures 3 and 4

\section{zoobank.org/913957CD-9342-4743-ACE2-0A7914FDCB3F}

Type material. Holotype: No. 10938 (male); Dominican amber (Lower Miocene); Smithsonian Institution Entomology Department; Brodzinsky/ Lopez-Penha Collection.

Etymology. The name is dedicated to Prof. Neal Evenhuis, the eminent specialist on Diptera, author of the Catalogue of the Fossil Flies of the World (Insecta: Diptera).

Diagnosis. Rostrum comparatively elongated, but only a little longer than length of head, approximately $1 / 5$ the length of antenna; vein $R_{2+3+4}$ elongated, slightly curved, twice as long as vein Rs; cross-vein $\mathrm{m}$-cu in the middle of $\mathrm{d}$-cell basal part; outer gonostylus narrow; inner gonostylus twice as long as outer gonostylus.

Comparisons. Helius (Helius) neali n. sp. differs from Helius collemus Podenas and Poinar, 2012 and Helius (Helius) oosterbroeki n. sp. described below, especially by the wing venation and the relation between the length of rostrum, palpus, antenna and head. In $H$. (H.) oosterbroeki n. sp. 


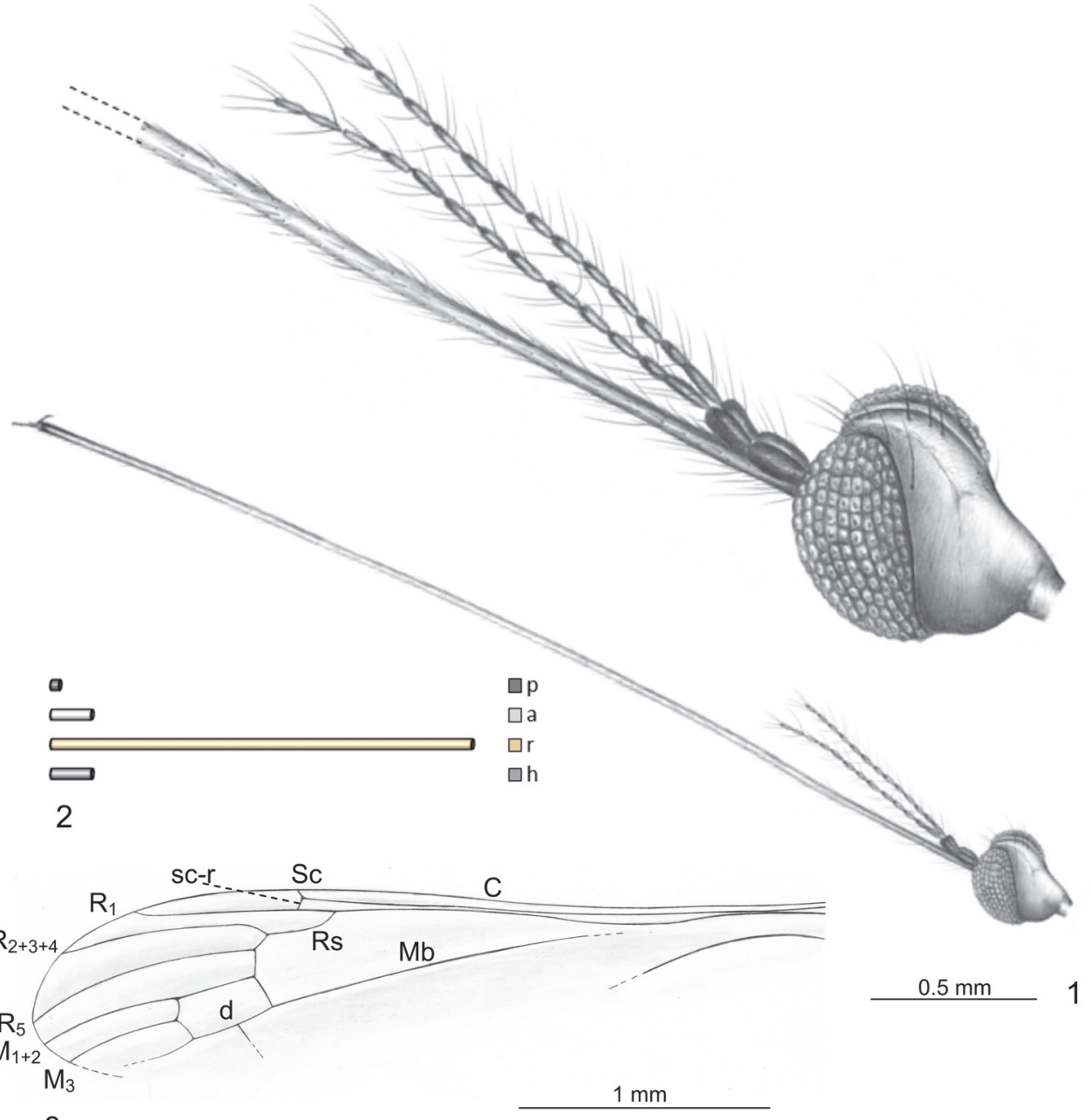

3

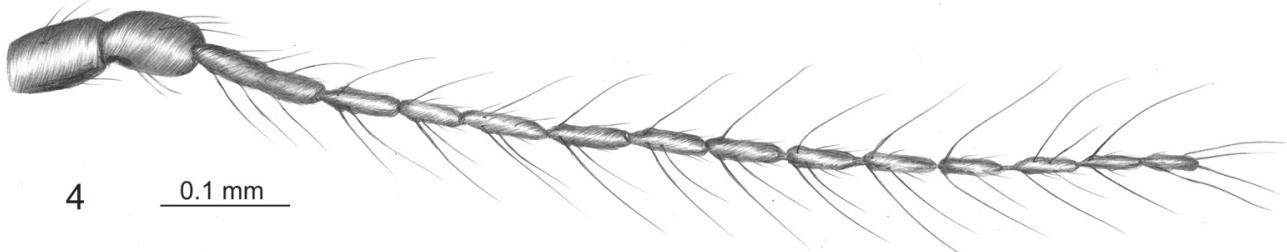

FIGURE 1. Elephantomyia (Elephantomyia) grata Podenas and Poinar, 2001, No. 5546 (sex unknown). 1, a drawing of the head (reconstructed) in latero-dorsal view; 2, a schematic representation of the relation between the length of palpi $(p)$, antenna (a), rostrum ( $r$ ) and head (h); 3, a drawing of the left wing venation; and 4, a drawing of the right antenna in latero-dorsal view.

rostrum is comparatively elongated, but a little shorter than head, $1 / 3$ the length of antenna and is shorter than palpus while in $H$. $(H$.) neali n. sp. rostrum is slightly longer than head, $1 / 5$ the length of antenna. In $H$. collemus rostrum is as long as remainder of head and almost twice as long as palpus, antenna are longer than rostrum. Moreover, in $H$. $\left(H\right.$.) neali $\mathrm{n}$. sp. vein $\mathrm{R}_{2+3+4}$ is elongated, slightly curved and twice as long as vein Rs while in $H$. $(H$.) oosterbroeki $\mathrm{n}$. sp. is short, Rs is very short and
$\mathrm{R}_{2+3+4}$ is only about $1 / 4$ longer than Rs. Cross-vein $\mathrm{m}$-cu in $H$. $(H$.) neali $\mathrm{n}$. sp. is situated in the middle of d-cell, in $H$. (H.) oosterbroeki n. sp. at the bifurcation of $\mathrm{Mb}$, in $\mathrm{H}$. collemus this vein is positioned shortly before the fork of $\mathrm{Mb}$. This new species differs also from $H$. collemus and $H$. $(H$.) oosterbroeki $\mathrm{n}$. sp. by the morphology of male genitalia. In $H$. $(H$.$) neali n. sp. inner gonostylus is twice as long as$ outer gonostylus, in $H$. (H.) oosterbroeki n. sp. 

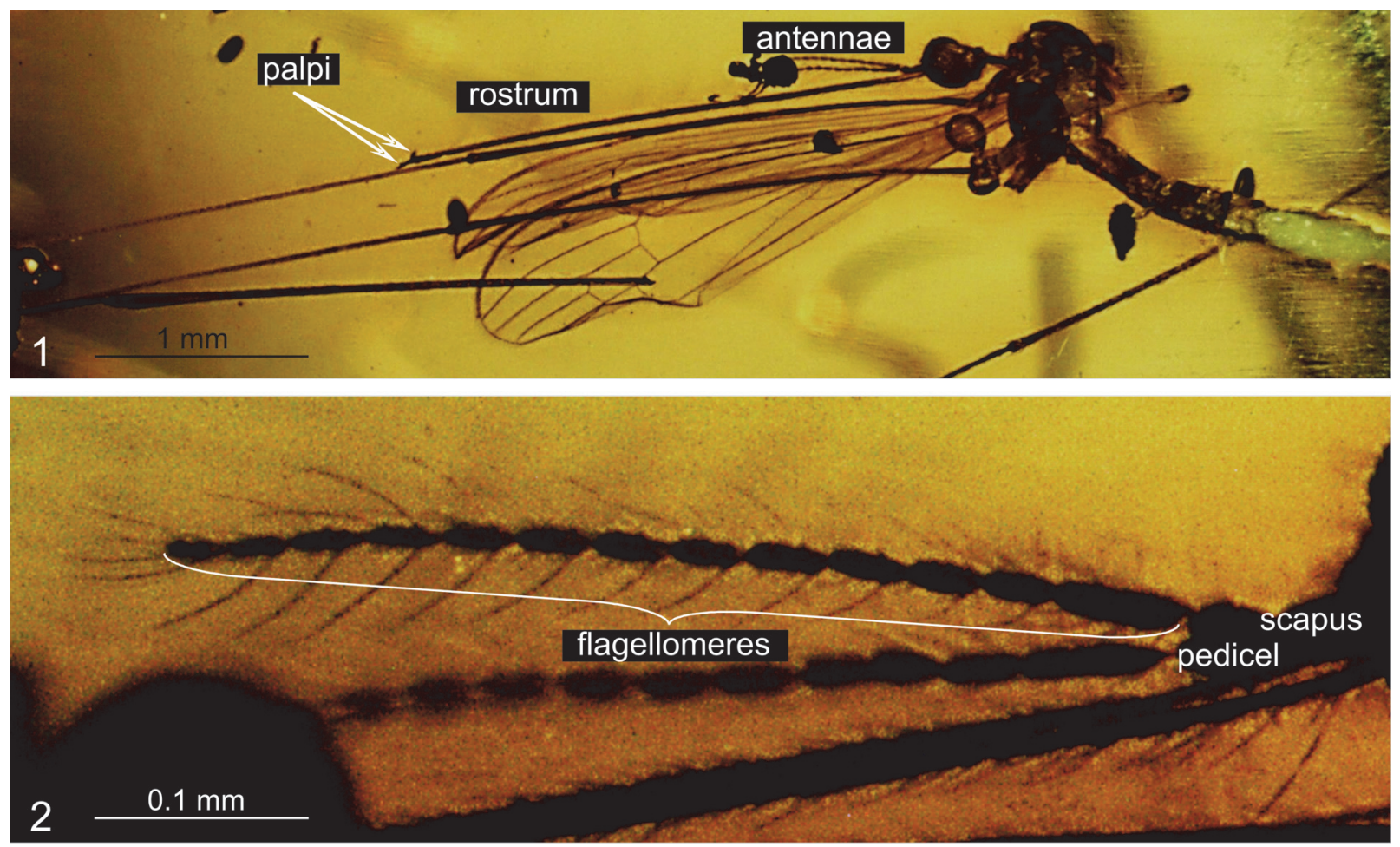

FIGURE 2. Elephantomyia (Elephantomyia) grata Podenas and Poinar, 2001, No. 5546 (sex unknown). 1, a photograph of the body in lateral view; and 2, a photograph of the right antenna in latero-dorsal view.

inner gonostylus is $1 / 4$ shorter than outer gonostylus.

Description. The body is pale brown, $4.38 \mathrm{~mm}$ long. Head (Figures 3.1, 4.2): width of head 0.49 $\mathrm{mm}$, rostrum elongated, but only a little longer than length of head, $0.14 \mathrm{~mm}$ long, distinctly widened at distal part (Figure 3.1, 3.2); antenna $0.80 \mathrm{~mm}$ long, 16-segmented; scapus elongated, cylindrical; pedicel barrel-like; first segment of flagellum oval, 1/3 longer than its width; the other flagellomeres oval, tapered toward the end of antennae, each flagellomere with two elongated setae, a little longer than the length of segments bearing them; palpi not preserved, the probably appearance is given on Figure 4.2. Thorax (Figure 4.1): the wing approximately $4.0 \mathrm{~mm}$ long, $1.2 \mathrm{~mm}$ wide, with distinctly visible pterostigma; Sc ending opposite $3 / 4$ the length of Rs; sc-r one its length before the end of Sc, $R_{1}$ ending opposite $1 / 2$ the length of $R_{2+3+4} ; r$ $r\left(R_{2}\right)$ atrophied; $R_{2+3+4}$ twice as long as vein $R s ; r-$ $m$ very short; $d$-cell huge, wide at the basal part; the sector of vein $M_{1+2}$ from $d$-cell to the edge of wing twice as long as d-cell; $\mathrm{m}$-cu in the middle of d-cell basal part. Abdomen: male genitalia: hypopygium and gonocoxites narrow, more than twice as long as width in widest area; inner gonos- tylus twice as long as outer gonostylus, strongly curved at the end (Figure 3.4). Female: unknown.

\section{Helius (Helius) oosterbroeki n. sp. Figures 5 and 6}

zoobank.org/8FCD3853-D3DA-47D9-A5D3-E245B8359B85

Type material. Holotype: No. 10189 (male); Dominican amber (Lower Miocene); Smithsonian Institution Entomology Departament; Brodzinsky/ Lopez-Penha Collection.

Etymology. The name is dedicated to Prof. Pjotr Oosterbroek, the eminent specialist on Diptera, author of the Catalogue of the Craneflies of the World.

Diagnosis. Rostrum comparatively elongated, but a little shorter than the length of head, 1/3 the length of antenna, shorter than palpus; Rs very short; $R_{2+3+4}$ short, about $1 / 4$ longer than Rs; d-cell rhomboid, 1/9 the length of wing; cross-vein m-cu at the bifurcation of $\mathrm{Mb}$; outer gonostylus 1/4 longer than inner gonostylus.

Comparisons. Helius $(H$.) oosterbroeki n. sp. differs from $H$. collemus and $H$. (H.) neali n. sp. by the wing venation, but especially by the relation between the length of rostrum, palpus, antenna and head. In $H$. $(H$.) neali n. sp. rostrum is slightly longer than head, $1 / 5$ the length of antenna while in 

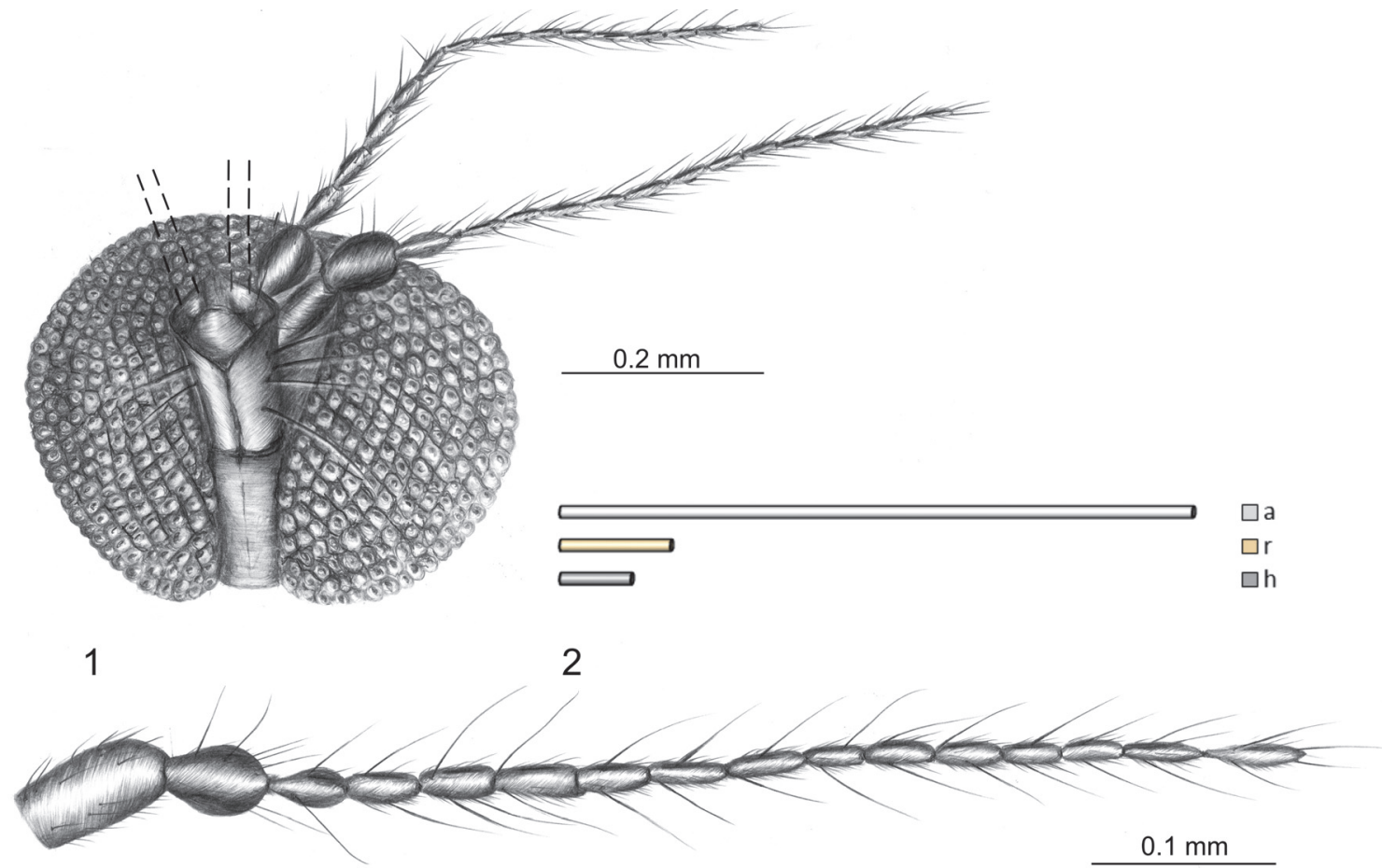

3

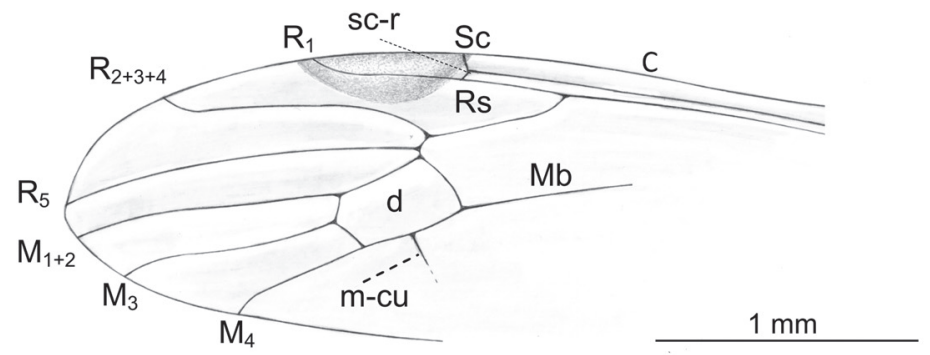

4

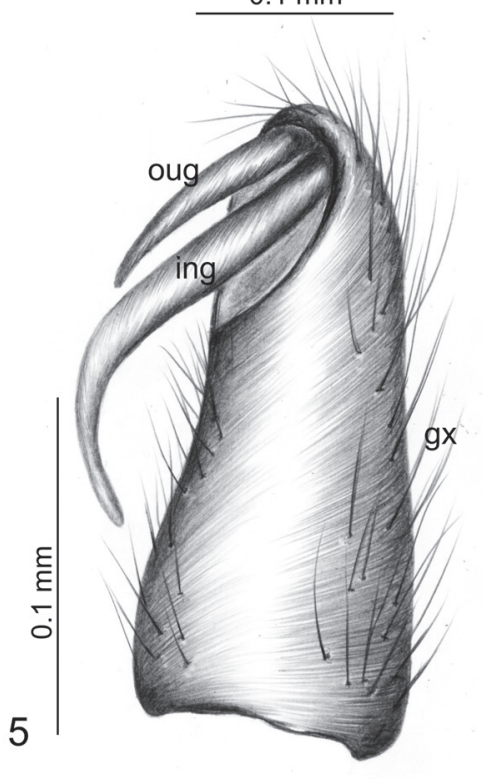

FIGURE 3. Helius (Helius) neali n. sp., No. 10938 (male). 1, a drawing of the head (reconstructed) in fronto-dorsal view; 2, a schematic representation of the relation between the length of antenna (a), rostrum ( $r$ ) and head (h); 3 , a drawing of the left antenna in ventral view; 4, a drawing of the left wing venation; and 5, a drawing of the right gonocoxite and gonostyles in ventral view. Abbreviation: gx, gonocoxite; ing, inner gonostylus; oug, outer gonostylus.

H. (H.) oosterbroeki n. sp. rostrum is comparatively elongated, but a little shorter than head, $1 / 3$ the length of antenna and is shorter than palpus. In $H$. collemus Podenas and Poinar, 2012 rostrum is as long as remainder of head and almost twice as long as palpus, antenna are longer than rostrum. Moreover, in $H$. (H.) oosterbroeki n. sp. is short, Rs is very short and $R_{2+3+4}$ about only $1 / 4$ longer than $\mathrm{Rs}$, in $H$. (H.) neali $\mathrm{n}$. sp. vein $\mathrm{R}_{2+3+4}$ is elongated, slightly curved and twice as long as vein Rs. Cross-vein m-cu in $H$. (H.) oosterbroeki n. sp. is at the bifurcation of $\mathrm{Mb}, H$. $(H$.) neali $\mathrm{n}$. sp. is situated in the middle of $d$-cell, in, in $H$. collemus this vein is positioned shortly before the fork of Mb. This new 

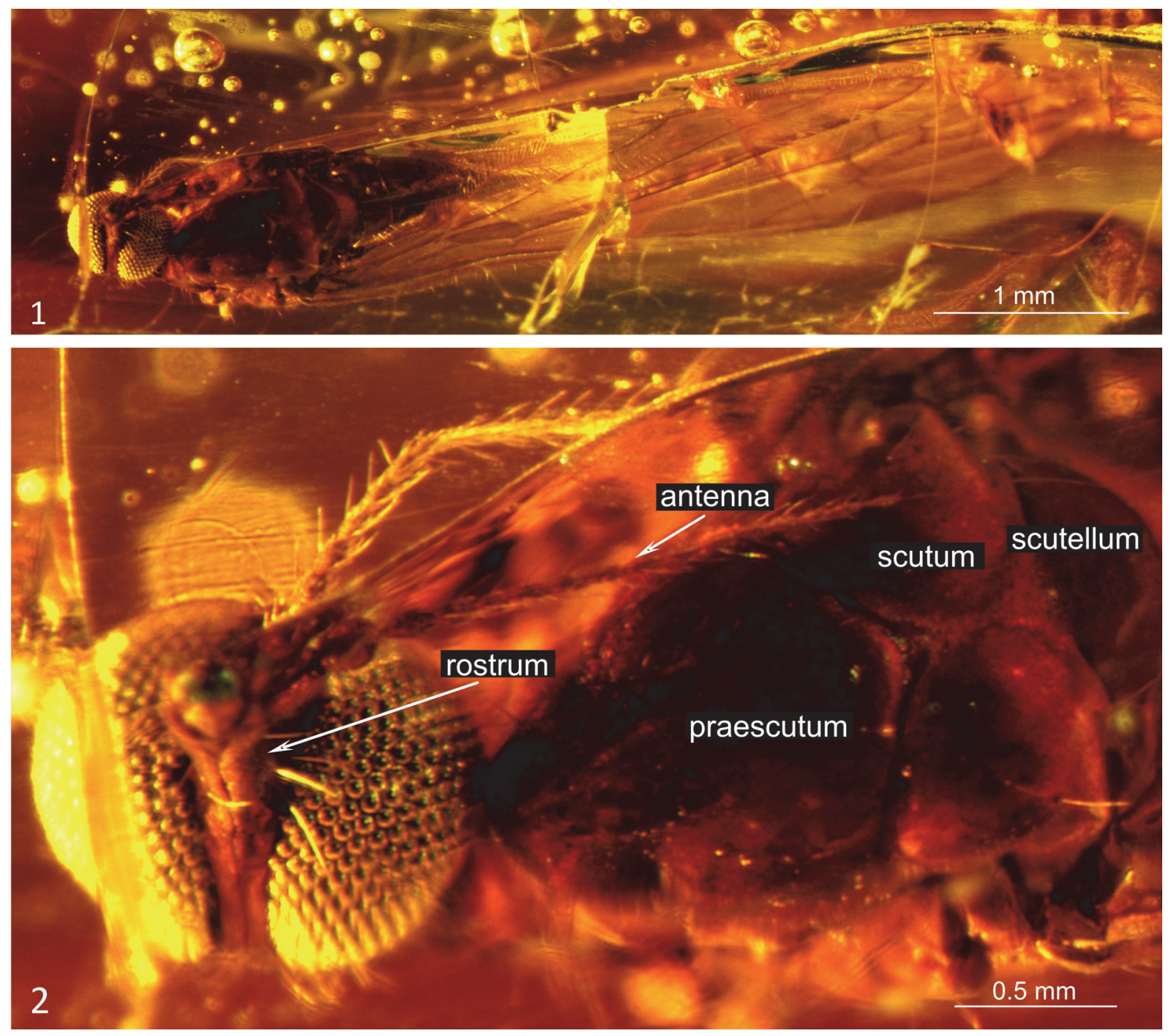

FIGURE 4. Helius (Helius) neali n. sp., No. 10938 (male). 1, a photograph of the body in fronto-dorsal view; and 2, a photograph of the head in fronto-dorsal view and the part of thorax in dorsal view.

species differ also from $H$. collemus and $H$. $(H$.) neali $\mathrm{n}$. sp. by the morphology of male genitalia. In $H$. $(H$.) oosterbroeki n. sp. inner gonostylus is $1 / 4$ shorter than outer gonostylus while in $H$. $(H$.) neali n. sp. inner gonostylus is twice as long as outer gonostylus.

Description. The body is brown, $3.25 \mathrm{~mm}$ long (Figure 6.1). Head (Figures 5.1, 6.2): Rostrum comparatively elongated, a little shorter than the length of head $0.29 \mathrm{~mm}$ (Figure 5.4), slightly widened at the end, width of head $0.55 \mathrm{~mm}$; antenna $0.78 \mathrm{~mm}$ long (Figure 5.2) 16-segmented; scape elongated, cylindrical; pedicel barrel-like; first flagellomere widened in the middle, twice as long as its width; the other flagellomeres oval, tapered toward the end of antennae; palpus $0.56 \mathrm{~mm}$ long (Figure
5.3), almost twice as long as rostrum, the last segment of palpus is elongated, almost equal in length to the penultimate one and other taken together. Thorax: wing (Figures 5.6, 6.1) $3.85 \mathrm{~mm}$ long, approximately $1.30 \mathrm{~mm}$ wide; vein Sc ending opposite the bifurcation of $\mathrm{Rb}$ on Rs and $\mathrm{R}_{1}$; Rs very short; sc-r two its length before the end of Sc; $R_{1}$ ending opposite $1 / 2$ the length of $R_{2+3+4} ; R_{2}(r-r)$ atrophied; $R_{2+3+4}$ short, only $1 / 4$ longer than $R s ; d-$ cell huge, narrowed at the basal part; the sector of $M_{1+2}$ from d-cell basal part to the edge of wing not more than twice as long as d-cell; $\mathrm{m}$-cu at bifurcation of $\mathrm{Mb} ; \mathrm{A}_{1}$ elongated, slightly waved; $\mathrm{A}_{2}$ slightly arched. Abdomen (Figure 6.1): hypopygium 0.51 $\mathrm{mm}$ long, gonocoxite elongated, three times longer 


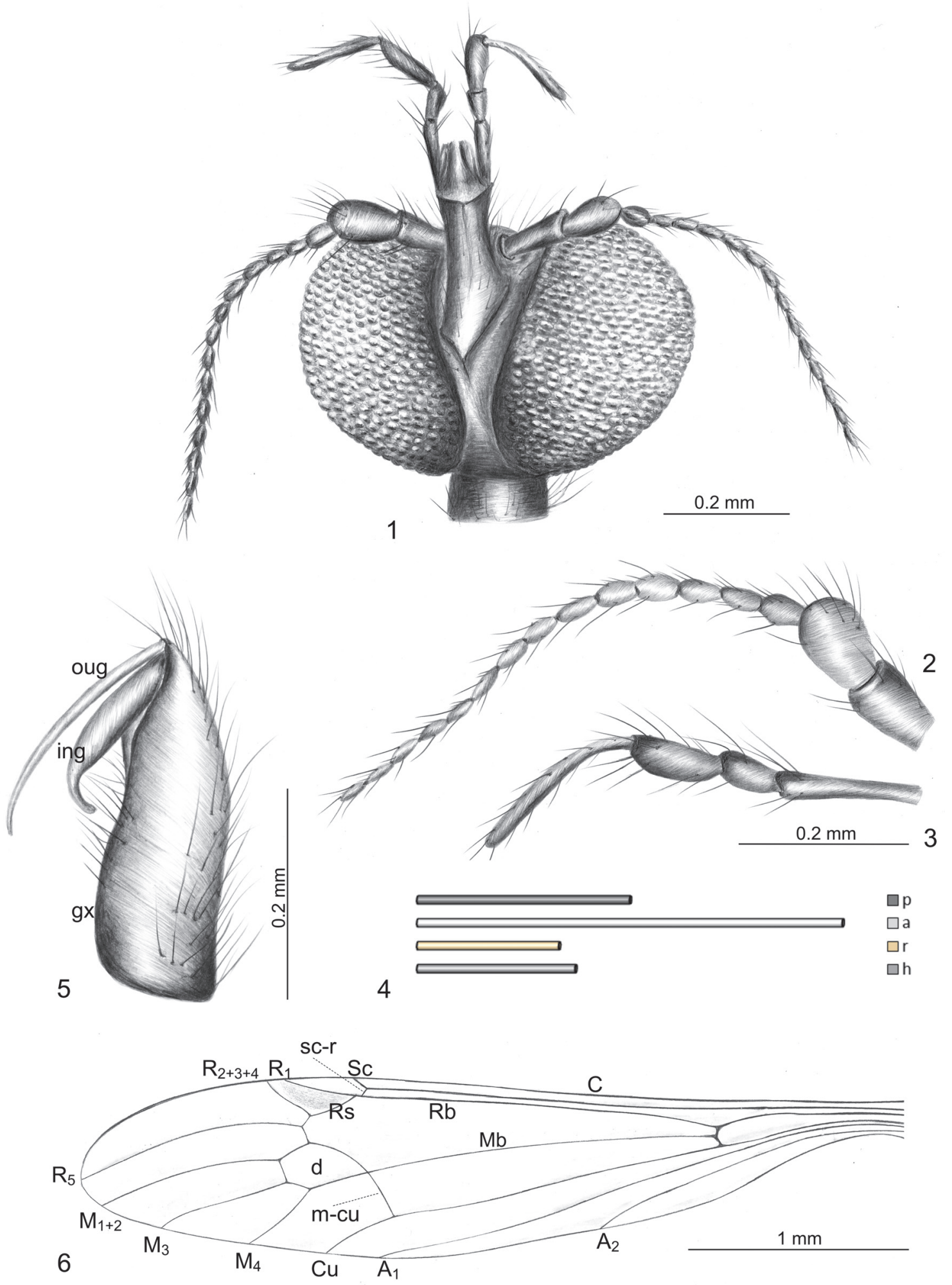

FIGURE 5. Helius (Helius) oosterbroeki n. sp., No. 10189 (male). 1, a drawing of the head (reconstructed) in frontoventral view; 2, a drawing of the right antenna in fronto-dorsal view; 3, a drawing of the right palpus in fronto-ventral view; 4, a schematic representation of the relation between the length of palpi ( $p$ ), antenna (a), rostrum ( $r$ ) and head (h); 5, a drawing of right gonocoxite and gonostyles in ventral view; and 6, a drawing of the right wing. Abbreviation: gx, gonocoxite; ing, inner gonostylus; oug, outer gonostylus. 


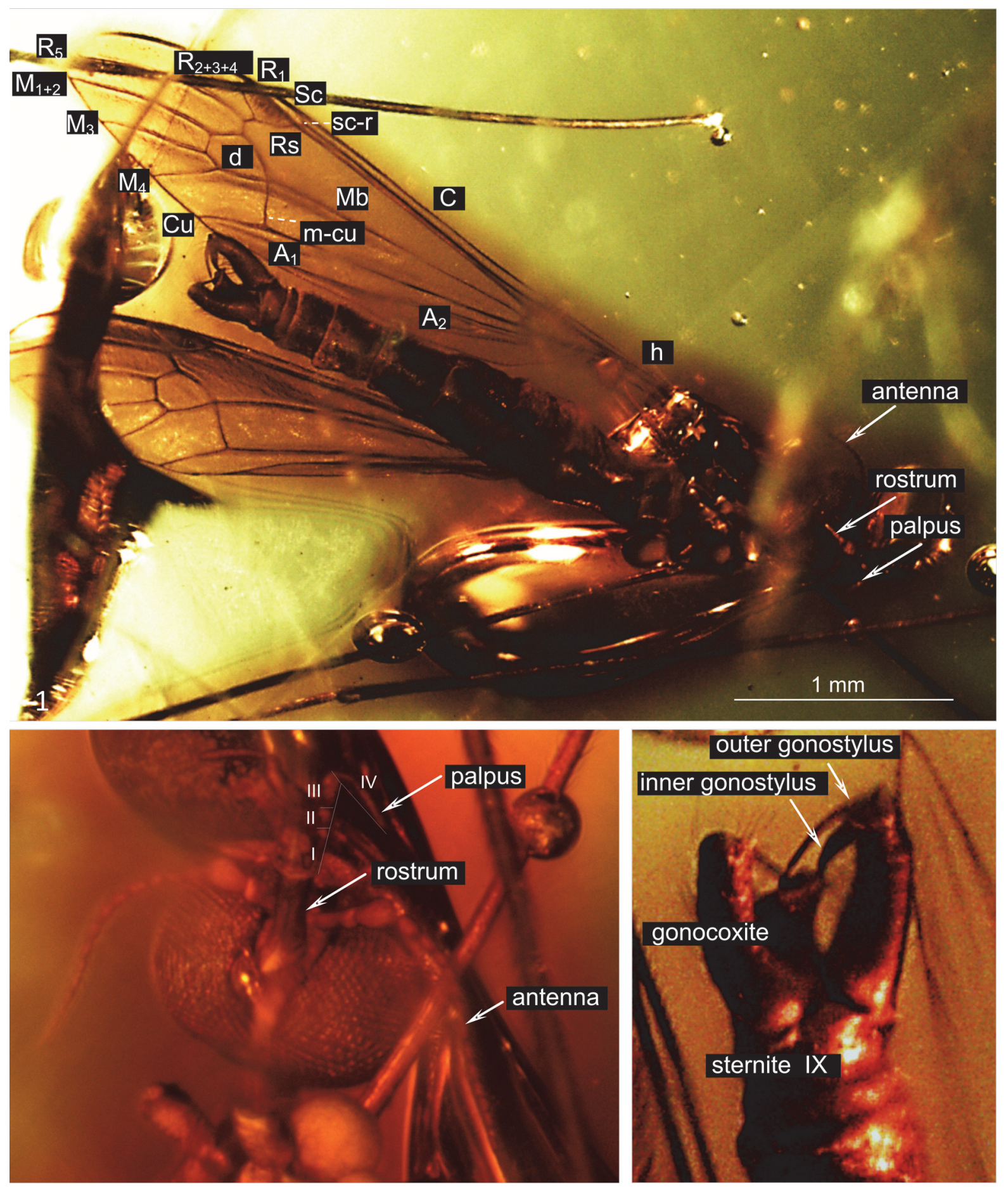

FIGURE 6. Helius (Helius) oosterbroeki n. sp., No. 10189 (male). 1, a photograph of the body in ventral view; 2, a photograph of the head in fronto-ventral view; and 3 , a photograph of hypopygium in ventral view. 

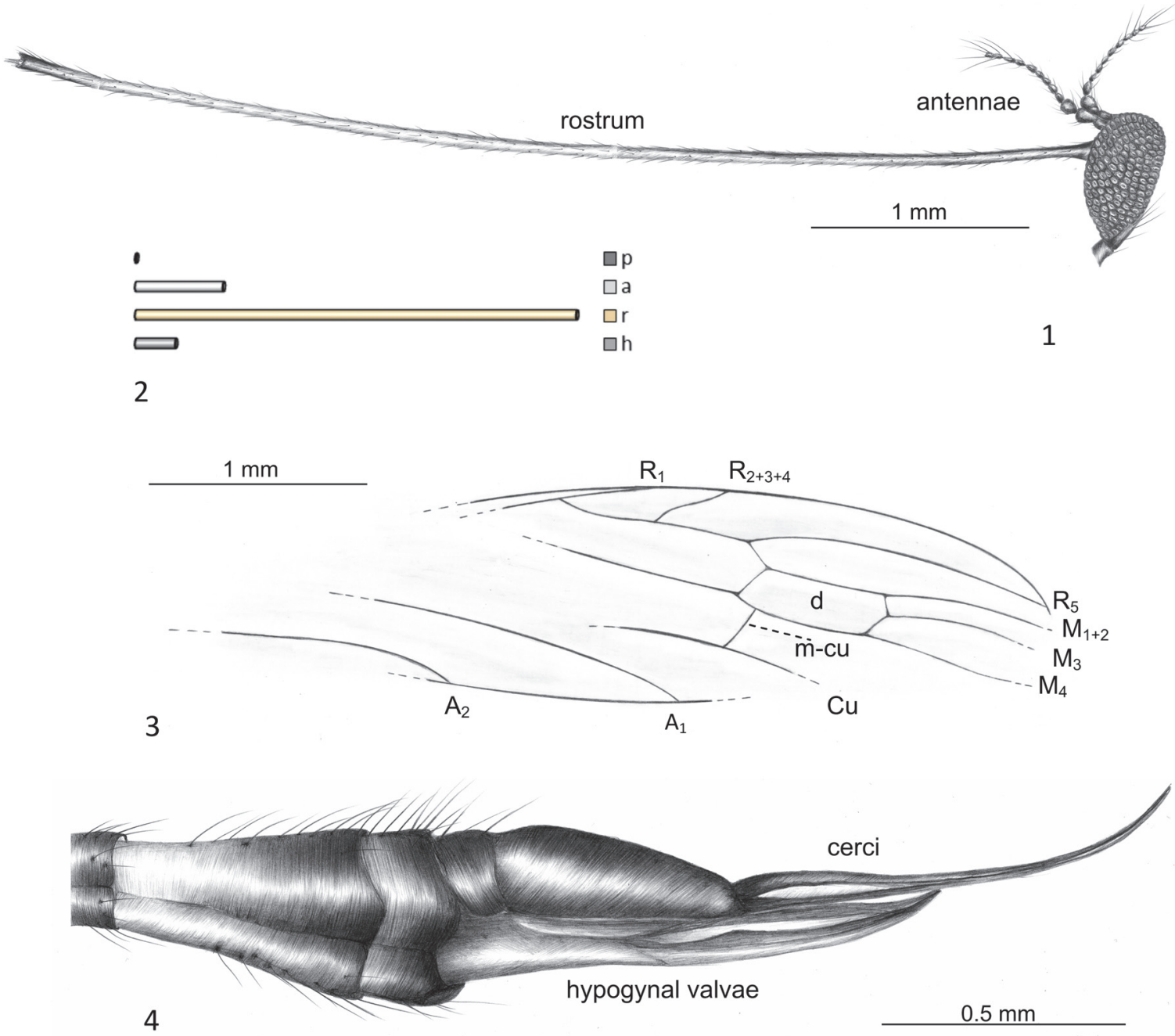

FIGURE 7. Toxorhina (Ceratocheilus) mexicana n. sp., No. PI II 1870 (female). 1, a drawing of the head (reconstructed) in lateral view; 2, a schematic representation of the relation between the length of palpi (p), antenna (a), rostrum ( $r$ ) and head (h); 3, a drawing of the left wing venation; and 4, a drawing of the ovipositor in latero-ventral view.

than its width; inner gonostylus $1 / 4$ shorter than outer gonostylus, strongly curved at the end directed to its basal part, widened at the base; outer gonostylus elongated, narrow, straight, slightly curved at the end; aedeagus elongated, wide (Figures 5.5, 6.3).

\section{Genus TOXORHINA Loew, 1851}

Type species. Toxorhina fragilis Loew, 1851, by subsequent designation by Osten Sacken (1869, p. 113).

Subgenus CERATOCHEILUS Wesché, 1910

Type species. Ceratocheilus winnsampsoni Wesché, 1910.
The genus is represented by almost 150 extant species, occurring mainly in Australian and Oceanian region. Over 30 species were reported from the Neotropic and Afrotropic. In Palearctic Region the genus Toxorhina is not represented (Oosterbroek, 2015).

Until recently, only three fossil species had been described from Eocene Baltic amber (Meunier, 1917), Miocene of Russia (Krzemiński and Freiwald, 1991) and Holocene of Madagascar (Meunier, 1906).

Toxorhina (Ceratocheilus) mexicana n. sp.

Figures 7 and 8

zoobank.org/031FC017-9417-4D28-9687-837BFEB0724C 

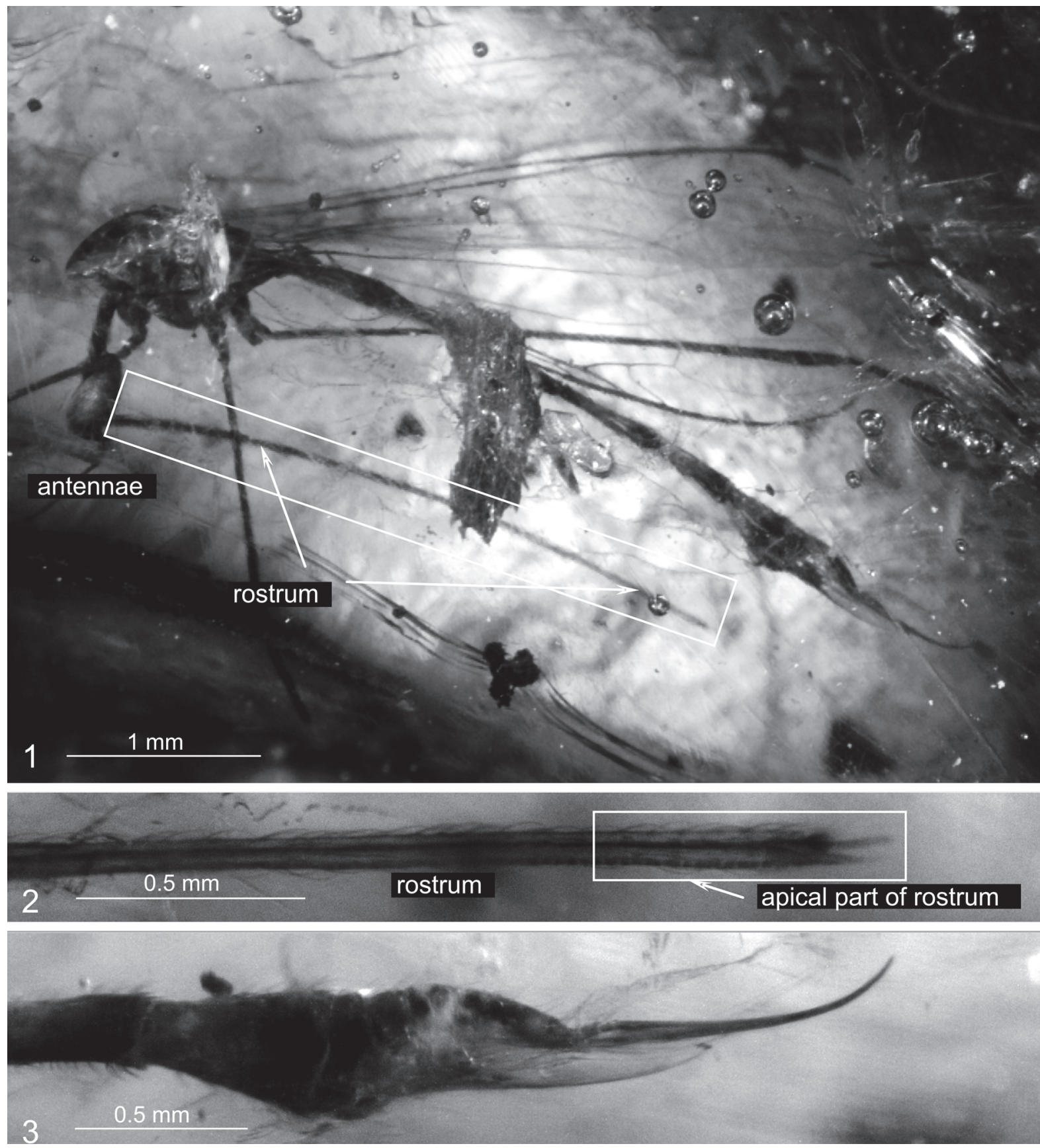

FIGURE 8. Toxorhina (Ceratocheilus) mexicana n. sp., No. PI II 1870 (female). 1, a photograph of the body in lateral view; 2, a photograph of the apical part of rostrum in lateral view; and 3, a photograph of the ovipositor in latero-ventral view.

Type material. Holotype: No. PI II 1870 (female); Mexican amber (Lower Miocene), Chiapas, Mexico; Natural History Museum, London, UK.

Etymology. The name of species is derived from Mexico, where the amber comes from.

Diagnosis. The Toxorhina (Ceratocheilus) mexicana $\mathrm{n}$. sp. differs from all fossil and extant species from South and Central America by very short vein
$R_{2+3+4}$, equal in length of vein $R s$; cross-vein $m-c u$ is positioned distinctly behind the bifurcation of $\mathrm{Mb}$, it differ also by very elongated, narrow ovipositor.

Remarks. From South and Central America only two localities with fossil remains are known-Santana Formation and localities from where the Dominican amber comes from. To that day, only a few Limoniidae have been discovered from these 
localities. Hence, each new finding is very important and considerably enriches our knowledge about evolution of this family in the Neotropical Region. The new species, Toxorhina (Ceratocheilus) mexicana $\mathrm{n}$. sp. is the first representative of Toxorhina Loew, 1851 from Mexican amber. Until now, only 11 species have been described from South and Central America, one of them from Mexico. In 2001, Podenas and Poinar noticed a partially preserved specimen of Toxorhina (Ceratocheilus) from the Dominican amber, with no preserved genitalia and unknown sex. During a few last years, any new Recent species of the genus have been described from the Dominican Republic. Description. The specimen is well preserved, but without part of a wing, the second wing is partially crinkled, $4.66 \mathrm{~mm}$ long. The body $7.10 \mathrm{~mm}$ long, dark brown, the basal part of tergites and sternites pale brown, the distal part of tergites and sternites almost black, ovipositor elongated. Head (Figures 7.1, 8.1): small, $0.37 \mathrm{~mm}$ long with very elongated rostrum $4.67 \mathrm{~mm}$ long (Figure 7.2), rostrum slightly longer than wing length (Figure 8.1), apical part of rostrum dainty with palpus relatively slender, probably 2-segmented (Figure 8.2); antenna $0.81 \mathrm{~mm}$ long, 12-segmented (not well preserved); pedicel elongated, cylindrical; scape huge, conicle; flagellomeres short, barrel like, tapered to the end of antenna, with very long and conspicuous setae (verticils) toward the apical part of antennae. Thorax (Figure 8.1): brown, legs very elongated, partially preserved in mentioned specimen, wing (Figures 7.3, 8.1) $4.66 \mathrm{~mm}$ long, $1.02 \mathrm{~mm}$ wide, vein $\mathrm{Sc}$ relatively short, vein $\mathrm{Rs}$ and basal section of $R_{5}$ almost equal in length, nearly straight, $R_{2+3+4}$ almost equal in length of $\mathrm{Rs}$, d-cell elongated, twice as long as wide, $M_{3}$ approximately $1 / 3$ longer than $\mathrm{d}$-cell, $\mathrm{m}$-cu behind the bifurcation of $\mathrm{Mb}, \mathrm{A}_{1}$ almost straight, $\mathrm{A}_{2}$ slightly waved. Abdomen (Figures $7.4,8.3$ ): female genitalia: ovipositor very elongated, narrow and slender (Figures 7.4, 8.3), $1.58 \mathrm{~mm}$ long with hypogynal valves wide, cerci narrow, longer than hypogynal valves.

\section{DISCUSSION}

New species of Toxorhina belongs to subgenus Ceratocheilus and is characterized by, typical for subgenus, a very elongated rostrum, much longer than half the body length and reduced palpi. The representatives of genus Helius, which are characterized by more or less elongated rostrum, and atrophy of cross-vein r-r $\left(R_{2}\right)$, or by the characteristic morphology of hypopygium and elongated last segment of palpi of species of this genus are easily recognizable among fossil Limoniidae and occur also in Dominican amber.

Among inclusions, we found the representatives of one known species, $H$. collemus, which is characterized by a small body compared to other species of the genus with general body coloration in light brown, rostrum 2.5x as long as remainder of head; with antenna slightly longer than rostrum, twice as long as palpus, wing shorter than body, without pigmented areas except stigma, long and narrow gonocoxite, both pairs of gonostyles long and narrow and with inner gonostylus with a slightly curved distal part. It is characterized also by short veins $R s$ and $R_{3}$, the tip of $R_{3}$ nearly reaches the tip of $R_{1}$, long vein $r-m$ and vein Sc extending no farther than the base of Rs. Crossvein $\mathrm{m}$-cu in this species is positioned shortly before the fork of Mb (Podenas and Poinar, 2012). The new species $H$. $(H$.) neali n. sp. differ from $H$. collemus especially by wing venation and morphology of mouthpart. It is characterized by a comparatively short rostrum, only a little longer than head length. Antennae of this species are much longer than rostrum. Vein Rs is elongated in this species, vein $S c$ elongated ending opposite $3 / 4$ vein $R s$, cross-vein $r-m$ is comparatively short, vein $R_{1}$ ending opposite half the length of $R_{3}$, cross-vein m-cu is positioned in half of d-cell basal part. The $H$. $(H$.) oosterbroeki n. sp. is characterized by short vein $R s$ and vein $R_{3}$, the tip of $R_{3}$ nearly reaches the tip of $R_{1}$, Sc ending just before the base of Rs, like in $H$. collemus, and the position of cross-vein m-cu is similar (at the bifurcation of $\mathrm{Mb}$ ) but male genitalia are different. Hypopygium is massive, gonocoxite wide, outer gonostylus is tiny and straight, elongated, inner gonostylus wide. This new species differs also from $H$. collemus by morphology of mouthpart. Rostrum in new species is elongated, as long as head but shorter than in $\mathrm{H}$. collemus where rostrum is $2.5 \mathrm{x}$ as long as remainder of head. Antennae and palpi are much longer than rostrum in this new species.

\section{CONCLUSION}

Descriptions of a new taxa are important for understanding the evolutionary history of Limoniidae. Such data allow the verification and testing the further phylogenetic hypotheses, as well as evolutionary scenarios of this family of crane-flies. New palaeoentomological data are very important for further comparative morphological analyses. A better knowledge of fossil Limoniidae made possible to provide palaeohabitats reconstructions and 
ecological interpretations of the past environments, in which these insects existed.

\section{ACKNOWLEDGEMENTS}

We would like to thank the Curator of Smithsonian Institution, Entomology Department; Brodzinsky/Lopez-Penha Collection, USA for lending the material to our disposal. We are deeply indebted to J. Ohimor, MA (Centre for Language Studies, University of Rzeszów) for his proof-reading of the material. We would like to acknowledge the reviewers for their important, very valuable advice and comments.

\section{REFERENCES}

Alexander, C.P. 1931. Crane flies of the Baltic Amber (Diptera). Bernstein-Forschungen, 2:1-135.

Bigot, J.M.F. 1854. Essai d'une classification générale et synoptique de l'ordre des insectes diptères (3è memoire). Tribu de Tipulidii (mihi). Annales de la Sociéte Entomologique de France, 3(2):447-482. (In French)

Evenhuis, N.L. 1994. Catalogue of the Fossil Flies of the World (Insecta: Diptera). Backhuys, Leiden.

Grimaldi, D. 1995. On the Age of Dominican Amber, p. 111. In Anderson, K.B. and Crelling, J.C. (eds.), Amber, Resinites, and Fossil Resins. ACS Symposium Series, Vol. 617. ACS publications, Washington.

Iturralde-Vinent, M.A. and MacPhee, R.D.E. 1996. Age and Paleogeographical Origin of Dominican Amber. American Association for the Advancement of Science, 273, 5283:1850-1852.

Kania, I. 2014. Subfamily Limoniinae Speiser, 1909 (Diptera, Limoniidae) from Baltic amber (Eocene): the genus Helius Lepeletier \& Serville, 1828. Zootaxa, 3814(3):333-352. doi:10.11646/zootaxa.3814.3.2

Kania, I. 2015. Subfamily Limoniinae Speiser, 1909 (Diptera, Limoniidae) from Baltic Amber (Eocene): The Genus Elephantomyia Osten Sacken, 1860. PLoS ONE, 10(2):e0117434. doi:10.1371/journal.pone. 0117434

Kania, I., Krzemiński, W., and Azar, D. 2013. The oldest representative of Helius Lepeletier \& Serville 1828 (Limoniidae, Diptera) from Lebanese amber (Early Cretaceous). Insect Systematic \& Evolution, 44:1-8. Available at: http:// booksandjournals.brillonline.com/ content/journals/10.1163/1876312x-44032093

Kimura, H., Tsukada, Y, Mlta, H., Yamamoto, Y., Chujo, R., and Yukawa, T. 2006. A spectroscopic index for estimating the age of amber. Bulletin of the Chemical Society of Japan, 79:451-453.

Krzemiński, W. 1985. Limoniidae (Diptera, Nematocera) from Baltic amber (in the collection of the Museum of the Earth in Warsaw). Part I. Subfamily Limoniinae. Prace Muzeum Ziemi, 37:113-117.
Krzemiński, W. 1991. A first fossil Helius (Diptera, Limoniidae) from North America. Acta Zoologica Cracoviensia, 34:311-313.

Krzemiński, W. 1992. Limoniidae (Diptera, Nematocera) from Dominican amber. I. Genus Molophilus Curtis, 1833. Acta zoologica cracoviensia, 35:107-111.

Krzemiński, W. 1993. Fossil Tipulomorpha (Diptera, Nematocera) from Baltic amber (Upper Eocene).Revision of the genus Helius Lepeletier et Serville (Limoniidae). Acta Zoologica Cracoviensia, 35:597601.

Krzemiński, W. 2002. Three new species of the genus Helius Lepeletier \& Serville (Diptera, Limoniidae) from the Middle Miocene of Stavropol (northern Caucasus, Russia). Acta Zoologica Cracoviensia, 45(4):317-320.

Krzemiński, W. and Freiwald, A. 1991. Toxorhina (Ceratocheilus) caucasiensis, a new species from the Middle Miocene of Stavropol (northern Caucasus, USSR) (Diptera, Limoniidae). Palaontologische Zeitschrift, 65(1/2):153-155.

Krzemiński, W., Kania, I., and Azar, D. 2014. The Early Cretaceous evidence of rapid evolution of the genus Helius Lepeletier \& Serville 1828 (Limoniidae, Diptera). Cretaceous Research, 48: 96-101.

Krzemiński, W., Kania, I., and Krzemińska, E. 2010. A new species of Dactylolabis (Eobothrophorus) from Baltic amber (Diptera: Limoniidae). Acta Geologica Sinica (English Edition), 84(4):768-771.

Lambert, J.B., Frye, S., and Poinar, G.O., Jr. 1985. Amber from the Dominican Republic: analysis by nuclear magnetic resonance spectroscopy. Archaeomelly, 27:43-51.

Lepeletier, A.L.M. and Serville, J.G.A. 1828. Entomologie, ou histoire naturelle des crustacés, des arachnides et des insectes. Encyclopedie Methodique, Histoire Naturelle, 10:345-833. (In French)

Linnaeus, C. 1758. Systema nature per regna tria naturae, secundum classes, ordines, genera, species, cum caracteribus, differentiis, synonymi, locis. Tomus I. Editio decima, reformata. L. Salvii, Holmiae [= Stockholm]. (In Latin)

Loew, H. 1850. Über den Bernstein Und die Bernsteinfauna. Program der Keiserischen Realschule Meseritz, pp. 1-44. (In German)

Loew, H. 1851. Beschreibung einiger neuen Tipularia terricola. Linnaea Entomologica, 5:385-418. (In German)

Meigen, J.W. 1803. Versuch einer neuen Gattungs Eintheilung der europaischen zweiflugligen Insekten. Magazin der Insektenkunde, 2: 259-281. (In German)

Meigen, J.W. 1818. Systematische Beschreibung der bekannten europäischen zweiflügeligen Insecten. Erster Theil. F.W. Forstmann, Aachen. (In German)

Meunier, F. 1906. Monographie des Tipulidae et des Dixidae de l'ambre de la Baltique. Annales des Science Naturelle Zoologie, 4:349-401. (In German)

Meunier, F. 1917. Ueber einige Mycetophiliden und Tipulidendes Bernsteins nebst Beschreibung der Gattung 
Palaeotanypeza (Tanypezinae) derselben Formation. Neues Jahrbuch fur Mineralogie, Geologie und Palaontologie, 1917(3):73-106. (In German)

Oosterbroek, P. 2015. Catalogue of the Crane-flies of the World. (Diptera, Tipuloidea: Pediciidae, Limoniidae, Cylindrotomidae, Tipulidae). Available at: http:// nlbif.eti.uva.nl/ccw/index.php

Osten Sacken, C.R. 1860. New genera and species of North American Tipulidae with short palpi, with an attempt at a new classification of the tribe. Proceedings of the Academy of Natural Sciences of Philadelphia, 1859:197-256.

Osten Sacken, C.R. 1869. Monographs of the Diptera of North America. Part IV. Smithsonian Miscellaneous Collections 8 (219).

Penney, D. 2010. Dominican amber, p. 22-41. In Penney, D. (ed.), Biodiversity in Fossils in Amber from Major World Deposits. Sri Scientific Press. Manchester.

Podenas, S. 2002. New species of Helius crane flies (Diptera: Limoniidae) from Baltic amber (Eocene). Mitteilungen aus dem Geologisch-Paläontologischen Institut der Universität Hamburg, 86:229238.

Podenas, S. 2003. Dactylolabis crane flies (Diptera: Limoniidae) in Baltic amber (Eocene). Proceedings of the Academy of Natural Sciences of Philadelphia, 153(1):49-65.

Podenas, S. and Poinar, G.O., Jr. 1999. New crane flies (Diptera: Limoniidae) from Dominican amber. Proceedings of the Entomological Society of Washington, 101(3):595-610.

Podenas, S. and Poinar, G.O., Jr. 2001. New crane flies (Diptera: Tipulidae, Limoniidae) from Dominican and Mexican amber. Proceedings of the Entomological Society of Washington, 103(4):863-878.

Podenas, S. and Poinar, G.O., Jr. 2012. New shortpalped crane flies (Diptera: Limoniidae) from Mexican amber. Proceedings of the Entomological Society of Washington, 114(3):347-371.

Poinar, G.O., Jr. 1992. Life in Amber. Stanford University Press, Stanford.

Poinar, G.O., Jr. and Brown A. 2002. Hymenaea mexicana sp. nov. (Leguminosae: Caesalpinioideae) from
Mexican amber indicates Old World connections. Botanical Journal of the Linnean Society, 139:125132.

Rayner, R.J. and Waters, S.B. 1990. A Cretaceous crane-fly (Diptera: Tipulidae): 93 million years of stasis. Zoological Journal of the Linnean Society, 99:309-318

Ribeiro, G.C. 2003. A new fossil Helius (Diptera: Limoniidae) from Burmese amber. Studia Dipterologica, 9(2):403-408.

Rondani, C. 1841. Progetto di una classificazione in famiglie degli insetti ditteri Europei. Memoria terza per servir alla ditterologia italiana. Donati, Parma. (In Italian)

Solórzano-Kraemer M.M. 2007. Systematic, palaeoecology and palaeobiogeography of the insect fauna from Mexican amber. Palaeontographica, 282:1-133.

Speiser, P. 1909. Orthoptera. Orthoptera Nematocera. Wissenschaftliche Ergebnisse der Schwedischen Zoologische Expedition nach Kilimandjaro, Meru 10 (Diptera):31-65. (In German)

Statz, G. 1934. Neue Tipulidenfunde aus den Braunkohlen-Schiefern von Rott am Siebengebirge. Wissenschaftliche Mitteilungen der Verein für Natur und Heimatkunde, 1(3):90-106. (In German)

Statz, G. 1944. Neue Dipteren (Nematocera) aus dem Oberoligocän von Rott. III. Familie Limnobiidae (Stelzmücken). IV. Familie: Tipulidae (Schnaken). V. Familie: Culicidae (Stechmücken). Palaeontographica, (A), 95:93-120. (In German)

Stephens, J.F. 1829. The Nomenclature of British Insects; Being a Compendious List of Such Species as Are Contained in the Systematic Catalogue of British Insects, and Forming a Guide to Their Classification. Baldwin \& Cradock, London.

Wesché, W. 1910. On the new tipulid subfamily Ceratocheilinae. Journal of the Linnean Society of London, Zoology, 30:355-360.

Westwood, J.O. 1835. Insectorum novorum exoticorum (ex ordine Dipterorum) descriptiones. London and Edinburgh Philosophical Magazine, 3(6):280-281. (In Latin) 